\title{
PRACTICES OF THE FAMILY HEALTH TEAM: ADVISORS OF THE ACCESS TO THE HEALTH SERVICES? ${ }^{1}$
}

\author{
Anne Caroline Coelho Leal Árias Amorim², Marluce Maria Araújo Assis ${ }^{3}$, Adriano Maia dos Santos ${ }^{4}$, Maria \\ Salete Bessa Jorge ${ }^{5}$, Maria Lúcia Silva Servo ${ }^{6}$
}

\begin{abstract}
${ }^{1}$ Article resulting from a study which received financial support from the National Council for Scientific and Technological Development (CNPq) - Process n. 307314/2007-3.

${ }^{2}$ M.Sc. in Collective Health. Assistant Professor II of the Undergraduate Courses in Nursing and Medicine of the Residency Program in a Professional Area of Health - Emergency Nursing and of the Multi-professional Residency in Family Health of the Universidade Federal do Vale de São Francisco. Petrolina, Pernambuco, Brazil. E-mail: anne.leal@univasf.edu.br

${ }^{3}$ Ph.D. in Nursing. Full Professor of the Department of Health of the Universidade Estadual de Feira de Santana (UEFS). CNPq researcher. Feira de Santana, Bahia, Brazil. E-mail: aassis@uefs.br

${ }^{4}$ Ph.D. in Public Health. Adjunct Professor of the Multidisciplinary Institute in Health, of the Universidade Federal da Bahia, Campus Anísio Teixeira. Vitória da Conquista, Bahia. Brazil. E-mail: maiaufba@ufba.br

${ }^{5}$ Ph.D. in Nursing. Full Professor of the Undergraduate Courses in Nursing and Medicine, of the Collective Health Program and of the Postgraduate Program in Clinical Care in Nursing and Health of the Universidade Estadual do Ceará. CNPq researcher. Fortaleza, Ceará. Brazil. E-mail: maria.salete.jorge@gmail.com

${ }^{6}$ Ph.D. in Nursing. Full Professor of the Undergraduate Course in Nursing of the Postgraduate Program in Collective Health and of the Professional Master's Degree in Nursing of the UEFS. Feira de Santana, Bahia, Brazil. E-mail: luciaservo@yahoo.com.br
\end{abstract}

\section{ABSTRACT: The study aimed to analyze the practices of the team in the Family Health Strategy, and how these guide the access to the health services. This was undertaken through qualitative research with systematic observation of the practice in three Family Health Centers as the data collection technique. The analyzing flowchart guided the analysis of the data. The results revealed that the access occurs, preferentially, through the family registration and the program actions directed towards specific groups. The procedure-centered practice guides the care in the Family Health Strategy, prioritizing the Emergency Room, depicted in emergency care. Some activities undertaken by the nurse were shown to be more susceptible to new therapeutic positions, shown by the service users' satisfaction. The study points to the need to advance in the re-signification of the practices, so as to strengthen improvement of access in the system's "gateway". \\ DESCRIPTORS: Health services accessibility. Family Health Pogram. Patient care team. Unified Health System. \\ PRÁTICAS DA EQUIPE DE SAÚDE DA FAMÍLIA: ORIENTADORAS DO ACESSO AOS SERVIÇOS DE SAÚDE?}

\begin{abstract}
RESUMO: O estudo teve por objetivo a análise das práticas da equipe na Estratégia Saúde da Família e como estas orientam o acesso aos serviços de saúde, o qual foi realizado em pesquisa qualitativa, com a observação sistemática da prática em três Unidades de Saúde da Família, como técnica de coleta de dados. O fluxograma analisador orientou a análise dos dados. Os resultados revelaram que o acesso ocorre, preferencialmente, por meio do cadastramento familiar e de ações programáticas voltadas para grupos específicos. A prática procedimento-centrada orienta a atenção na Estratégia Saúde da Família, priorizando o pronto-atendimento, retratado nas urgências/emergências. Algumas atividades, realizadas pelo enfermeiro, mostraram-se mais susceptíveis a novas posturas terapêuticas, manifestadas pela satisfação dos usuários. O estudo sinaliza para a necessidade de avançar na ressignificação das práticas para potencializar a melhoria do acesso na "porta de entrada" do sistema.
\end{abstract}

DESCRITORES: Acesso aos serviços de saúde. Programa Saúde da Família. Equipe de assistência ao paciente. Sistema Único de Saúde.

\section{LAS PRÁCTICAS DEL EQUIPO DE SALUD DE LA FAMILIA: DIRECTRICES DE ACCESO A SERVICIOS DE SALUD?}

RESUMEN: El estudio pretende revisar las prácticas del equipo en la estrategia de salud de la familia y como estos rigen el acceso a servicios de salud, que fue logrado en la investigación cualitativa con la observación sistemática de la práctica en tres unidades de salud de la familia como técnica de recogida de datos. El analizador de diagrama de flujo guiado el análisis de datos. Los resultados revelaron que el acceso realiza preferentemente a través del nombre de la familia y las acciones programáticas orientadas a grupos específicos. La práctica centrada en procedimiento Guía del estrategia de salud de la familia, priorizando la listo-habitación en urgências/emergências. Algunas actividades llevadas a cabo por la enfermera eran más susceptibles a nuevos enfoques terapéuticos, que se manifiesta por la satisfacción de los usuarios. El estudio señala la necesidad de avanzar en la (re) significación de las prácticas para mejorar el acceso mejorado en la "puerta" del sistema.

DESCRIPTORES: Accesibilidade a los servicios de salud. Programa de Salud Familiar. Equipo de aténcion al paciente. Sistema Único de Salud. 


\section{INTRODUCTION}

In the Brazilian context, many discussions occur regarding the health system, with emphasis on Primary Health Care (ABS), with a view to greater coverage and resolutive capacity of the actions proposed for the care network. The Family Health Strategy (ESF) is part of this network, in the search to overcome the model of health which is centered on disease and practices which are predominantly reactive; the aim is to reorganize the access based on this strategy as a "gateway" which is preferential and which articulates the health care network. ${ }^{1}$ Furthermore, the incorporation of innovative concepts and practices is sought, marked by different technologies for meeting the needs presented in the concrete spaces, where people build their histories and present their health-illness process. ${ }^{2-3}$

In this regard, the health practice can be brought together in acts protagonized by different social subjects, geared towards the changing of the context and, in this way, to allow counterpoints to the functional framework instituted, indicating relational, institutional and organizational changes, through instituting actions. ${ }^{4}$ That is, the health practices are engendered in different forms of organization of the teamwork, such as: "grouping team", which bases its practice in the overlapping of actions undertaken by a group of subject-workers to undertake works which are not mutually connected, and "integration team", which elaborates proposals of work inclined to the undertaking of comprehensive actions, consistent with the integrated and collaborative work of the health workers. ${ }^{5}$

The access, nevertheless, can be discussed based on specific dimensions, which describe the suitability between the service users and the health system: the availability, understood as a relationship between the quantity of attendance offered and the needs to be met; the relationship between what is offered and the demand of the service users in their social territory; the functional fit, perceived as the relationship between how what is offered is organized for accepting the service users and the capacity/skill of these in accepting the above-mentioned aspects and perceiving the convenience of the same. ${ }^{6-7}$

In a review of studies which also addressed practices of the Family Health Team (EqSF) as advisors of the access to the health services, works in their multiple dimensions were identified, relating the access to the geographical and social inequalities ${ }^{8}$ and the accessibility of the services, ${ }^{9}$ which go beyond the geographical dimension; the availability and functional organization of these; ${ }^{10}$ embracement as a guiding arrangement; ${ }^{11-12}$ and the supply and demand of the health services ${ }^{13}$ for meeting the individual and collective needs of the users of the Unified Health System (SUS).

However, gaps were observed in knowledge on the articulation of the issue referent to the practice of health and the connections established in the process of construction of access to the primary health network, including the ESF, even though some authors discuss the process of caring interconnected by the micropolicy of the area's work process, ${ }^{2,14}$ covering embracement as a necessary arrangement for viabilization of the access in the SUS network. ${ }^{11-12,14}$

In summary, this article, elaborated based on a Master's dissertation, defines the following guiding question: how is the practice of the EqSF operated, in order to guide the service users' access to the ESF? To this end, the study aimed to analyze the dynamic of the practices of the Family Health team as advisors of the access to the health services.

\section{METHODOLOGY}

The study's empirical field is located in the Semi-Arid Region of the Brazilian Northeast in the Brazilian State of Bahia, a component of the Family Health Expansion and Consolidation Project (PROESF). Under the Pact for Health, the municipality took control of the management of the health services, being responsible for a network of services which has $83 \mathrm{EqSF}$, covering $57 \%$ of the population in the urban area and $100 \%$ in the rural area. ${ }^{15}$ The municipality has a diversified network of medium and high technological density, and manages resources of approximately $\mathrm{R} \$ 60$ million/year, being a reference for nearly 80 municipalities of the Center-East and Center Health Macro-regions. ${ }^{16}$ The study was undertaken in three Family Health Centers (USF), through the systematic observation of the practice, totaling 74 hours. The inclusion criteria were: a complete EqSF (physician, nurse, dentist, nursing technician, Community Health Workers (ACS), and an oral health auxiliary or technician); workers who had been inserted in the team for a minimum of six months, and centers located in the three different areas of coverage.

The data were collected in the period July - December 2009, guided by a script, containing 
information relating to access to the ESF: type of demand, number of spaces, consultations scheduled, criteria for arranging consultations and the center's routine practices.

The analysis of the data was guided by the analyzing flowchart, ${ }^{17}$ a graphic representation of the path traveled by the service user in health centers, showing the interfaces between the subjects of the practice, their methods of action and how they interact, allowing a new understanding in relation to the practices in health, which is, essentially, a type of strength which operates in permanent action and in relation. The researchers, therefore, sought to establish interfaces between the access to the ESF and the practice undertaken by the health team.

In this regard, it is considered that any health services may be fitted in the sequence shown by the flowchart, presented in figure 1. It is an analysis of the objective and subjective elements which go beyond the production of the practice, and which are present in the different points of the flow of service users in the care network. These are represented by the entrance and exit of the global process of production identified in the health services, depicted, in the case in question, by the access, from the gateway in the ESF, through to the finalization of the therapeutic project.

The gateway is represented, symbolically, by an ellipse, characterized by the movement which, in one day, is made in the USF's "gateway", and in which some users end up arriving at the reception while others do not, this characterizing the moment of access. The reception, configured as a rectangle, is constituted in the different ways of organizing the attendance. The decision to offer services is represented by a lozenge, with the distinct criteria which the center uses for investigating whether what the service user brings as a problem shall be, or not, the object of intervention in this USF. The menu, the second rectangle, consists of the offer of specific services by the unit, that is, both the consultations undertaken in a doctor's surgery, and the attendance undertaken in the corridor, simply and rapidly, and which allow, or not, access to the center's practices. Finally, the exit ellipse describes what occurs with the service users who obtained some type of intervention and who were able to leave or return to the unit in various situations: discharge, by cure, death or abandonment of treatment; referrals for tests or other services of the care network and returns of widely differing types, from the service itself.

In the presentation of the results, constructed based on the observations of the practice, the flow of information acquired through the empirical research is detailed, deepening the flowchart depicted in figure $1 .{ }^{17}$

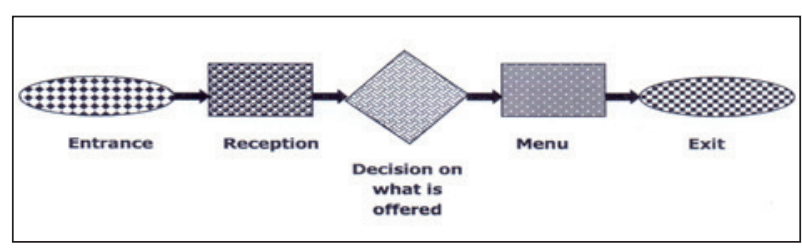

Figure 1 - Analyzing flowchart of the route followed by the user seeking attendance in the health services. Source: Merhy ${ }^{13-14}$

All the subjects observed received the terms of consent, containing explanations regarding the study, with a request for providing the necessary data and authorization for participation in the study. The research project was submitted to, and approved by, the Research Ethics Committee of the State University of Feira de Santana, under protocol n. 170/2008 (CAAE 0170005900008).

\section{PRESENTATION AND DISCUSSION OF THE RESULTS}

Learned during the systematic observation of the practice of the EqSF, the analytical summaries, represented in Figures 2, 3 and 4 confirm other studies undertaken in the region of the Recôncavo baiano* 11,18-19 and corroborate studies undertaken in other Brazilian states ${ }^{10,20-21}$ relating to the ESF allowing the broadening of access to some services at the primary level of care, although this has not constituted a space for attendance which assures the user's full access, as a 'gateway' in the health system..$^{22}$

The persistence of these problems reflects the inadequacy of the embracement undertaken in services in relation to the advances regarding the management of the work ${ }^{12,23-24}$ and challenges to the coordination of the care in the EqSF. ${ }^{25} \mathrm{Al}-$ lied to these problems, one may observe a care network which is insufficient in relation to the offering of services at medium and high technological density. ${ }^{13,22}$ These aspects require workers and managers to invest in actions which promote

\footnotetext{
* The northern-most edge of All Saints' Bay (Baia de Todos os Santos) in Bahia. Translator's note.
} 
health, articulated with appropriate investments in terms of financing, the acquisition of personnel, and development of relational skills, compatible with the comprehensiveness of the care.

Based on this assertion, organizational problems persist, related to the repressed demand and its implications for ensuring access to the set of activities offered, not always appropriately, capable of meeting the needs shown by the service users in the scenarios studied. This creates the opportunity for conflicts in the process of constructing the health practice. The repressed demand, as observed, continues to be related to the organizational aspects of the practice and to the persistent lack of resolutive capacity in centers with greater technological density, among other issues.
So as to evidence the analysis of the data in a more detailed way, three different situations are presented in relation to the service users' access to the practices of the EqSF, as shown in figures 2,3 and 4 .

Situation one, depicted in figure 2, shows that the embracement occurs in the reception, with access, preferentially, organized by service users registered in the USF, through family registration, and following the order of arrival. In the reception, the locus where the initial contact of the service user with the USF occurs, the priorities are directed to the Emergency Room, and programmatic attention to specific groups such as children, people with hypertension and diabetes, and pregnant women, among others.

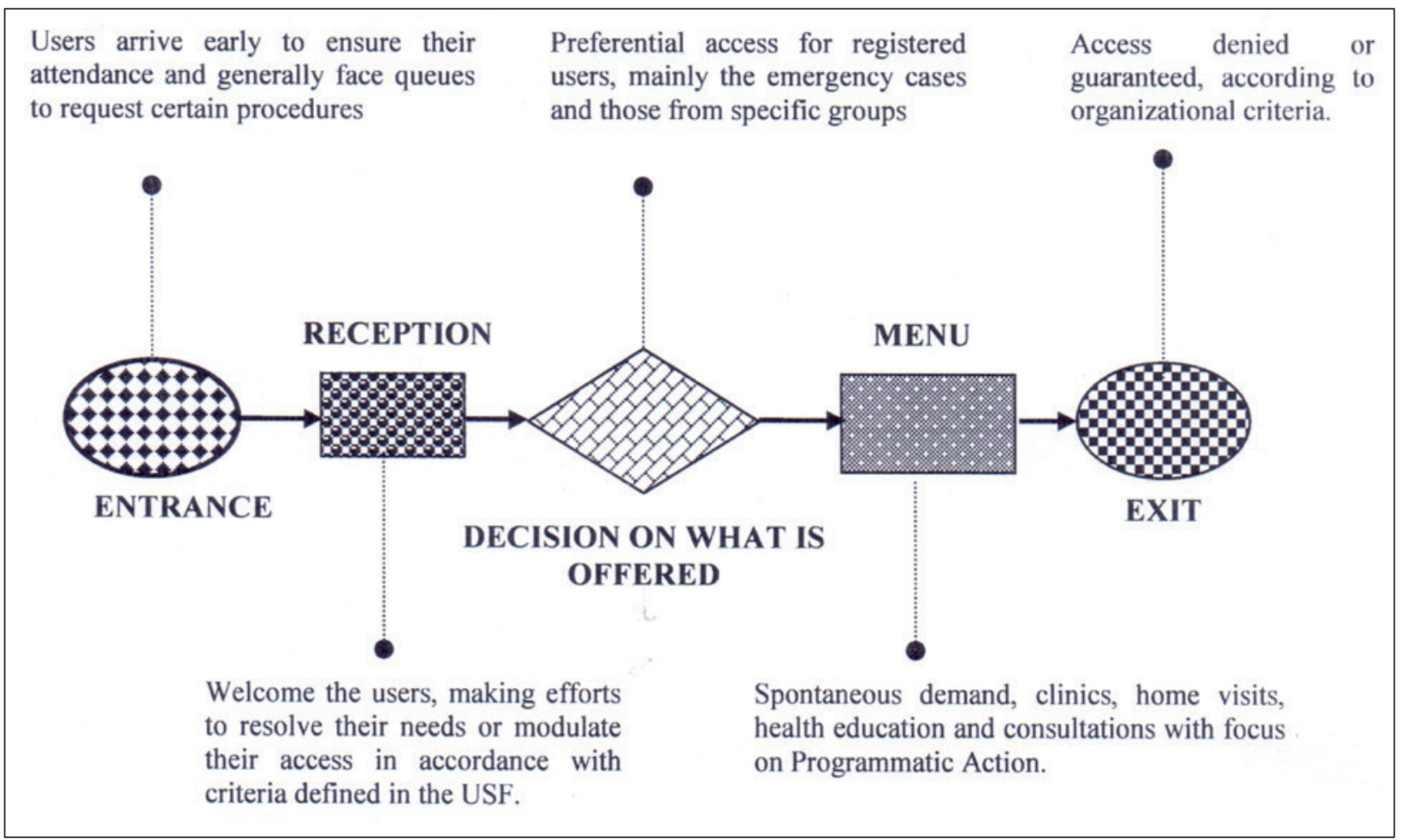

Figure 2 - Analyzing flowchart of the users' access to the practices of the Family Health Team (Situation One)

The service users experience the spontaneous demand to the health services, arriving early so as to ensure their attendance and, generally, facing queues in the professionals' different activities: medical consultations, dressings, vaccinations and other procedures.

In addition to the criteria described, the care is available for attendance for any citizen who, in an emergency situation, needs to be evaluated, and not only for residents in the area covered, registered by the ACS. Nevertheless, in spite of this openness to spontaneous demand, this possibility for attention is restricted by aspects such as: number of attendances/day, the order of arrival, and absence of professionals and materials, among others, which favor the non-resolution of an appreciable part of the social territory's demands, partially disqualifying the work process and causing loss of appropriate care. 
The criteria for arranging consultations by the health workers are variable, and depend on the center and on the team, with the exception of the physician, who, in all of the USF investigated, undertook these through weekly scheduling. The nursing attendance generally occurs by spontaneous demand, apart from in relation to groups which are prearranged. It may be observed, however, that in one of the centers, the nurse organizes his practice in parallel with the medical practice, through scheduling.

The oral health attendance occurs differently in the three centers, with the scheduling varying between monthly, three-monthly and without a defined period. It is noted that in all the USF observed, the new attendances in Dentistry, in order to undertake the complete treatment, are arranged after the conclusion of the others which were previously scheduled. However, even with this organizational dynamic, the offer of services is insufficient for the repressed demand from the areas covered by the centers, evidenced by the waiting lists and long queues at the centers' doors. Even so, all the dentists were praised for how they undertook their practice, most of which were certainly humanized, but contradictory in one center, in which we identified the non-embracement of one user in an emergency situation.

Some activities, such as talks in the waiting room, individual guidance and group discussions regarding specific health issues (diabetes and hypertension) among others were related to the nurses' practice, which was shown to be more susceptible to new therapeutic positions. The production of the care, undertaken by the above-mentioned professional, was shown to be innovative, welcoming and co-responsible for the majority of the service users. This satisfaction was presented at different points of the process of the production of the care: 1 ) at the time of reception, on being welcomed by the nurse; 2 ) in the act of the individual attention, through an easily-understood approach, determined by qualified listening and co-responsibilization, established between the nurse-user-team; 3) in the undertaking of collective activities, operated through guidance, lectures and community workshops; 4) in the referral of the demands presented by the service users to other services of the health care network, above all in services of medium and high technological density.

However, in the event of his need in primary care not being resolved, the service user is referred to the other levels of attention of the SUS, a critical point observed, due to the delay in the attendance and the unavailability of therapeutic spaces related to specialized medical attendance, complementary tests, and hospital inpatient treatment.

It is understood that good-quality health care is related to the adoption of embracing practices at all points of the care. In this regard, caring requires the reconstruction of the practices in health, ${ }^{26} \mathrm{com}$ patible with the humanization of the attendance and, these, in their turn, do not fir in the numerical and bureaucratic restrictions. This requires a broadened and inventive clinic which affects professionals and service users in the routine of the services. ${ }^{27}$ Hence, the practice of the team should consider biopsychosocial aspects, which in order to be grasped cause facilitated access, ${ }^{6}$ coordinated and continued care, and longitudinality,,$^{22,25}$ conformed in a contrary way to the various restrictions of access, as observed in the scenarios investigated.

However, the municipal management advises the teams to work with demand organized preferentially, delimiting the number of daily spaces. In particular, the preferential access for the specific groups, such as people with hypertension or diabetes, or those related to phases of life (children and women), can cause the exclusion of groups which need other approaches, given that there is greater resistance to the care and greater difficulty in adhering to the health services (men, adolescents). ${ }^{10,28}$ However, it is necessary to support the work based in the defense of the users' rights, compatible with the development of the link-responsibilization, based on the reversal of the procedure-centered model of care, adapting it to the clinical situation and uniqueness of each user. ${ }^{29-31}$

In situation two, figure 3, the embracement is organized in accordance with the clientele's adscription, while making an effort to resolve the peoples' needs, or seeking to refer them to the centers in which they will be attended. The "gateway" of the USF has a certain flexibility, seeking to attend the users, in any situation; although organizational criteria are established for the definition of the care, preferential access occurs for users of the area, except in emergency situations and in exceptional cases ('case by case' evaluation). Although the access is denied in many moments, it was also possible to perceive, due to the unpredictability of the time spent on the attendances, that the access was not always mediated by bureaucratic criteria (number of users per shift), because, regarding emergencies and exceptional cases, the workers base their behaviors in humane dimensions which allow the broadening of the team's caring acts. 


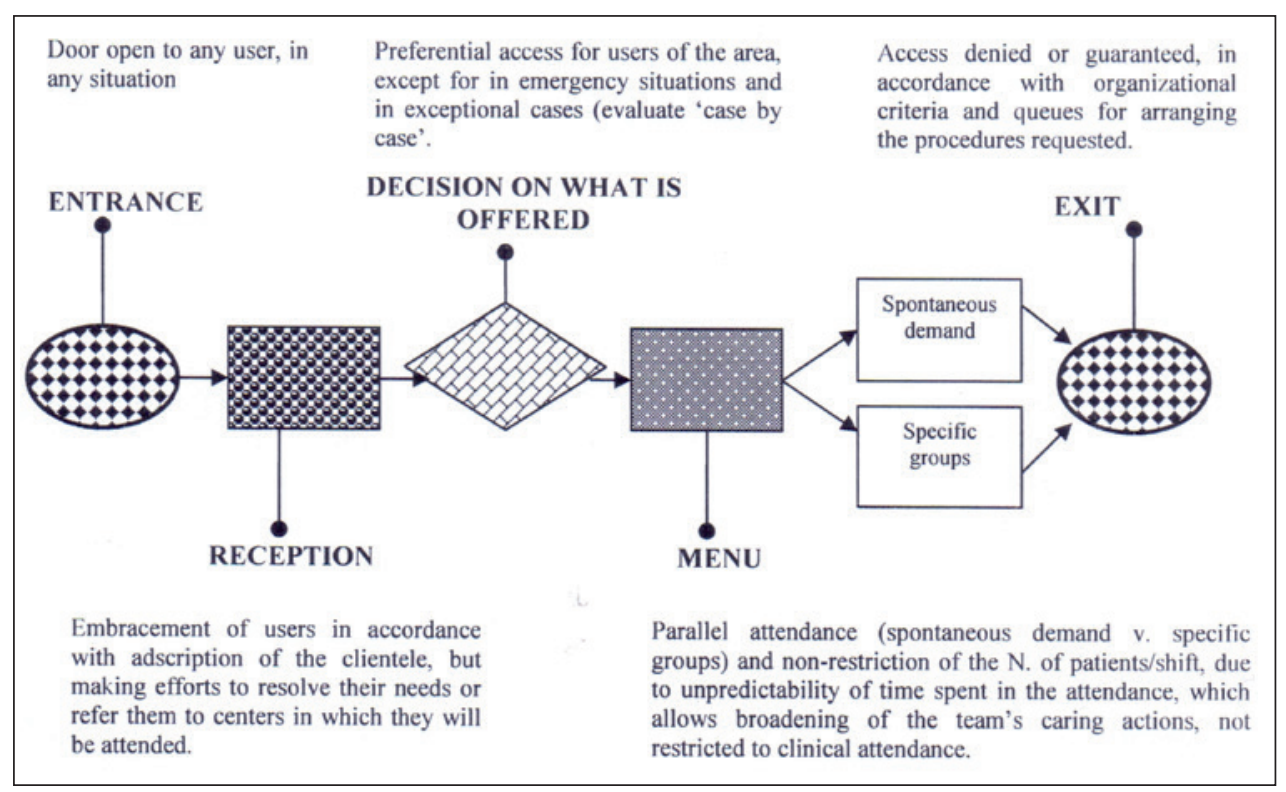

Figure 3 - Analyzing flowchart of users' access to the practices of the Family Health Team (Situation Two)

In situation three, evidenced in figure 4, the access is denied for some users or scheduled for a time which is incompatible with their needs. The scenario shows the users' frustration with the health system, demonstrating non-understanding (or non-acceptance) of how the offering of services is organized, and of the lack of embracement of their demands at the time of the act of the care. The user and her family members do not feel embraced and/or appropriately advised by the service, leading them to seek other centers in the SUS care network.

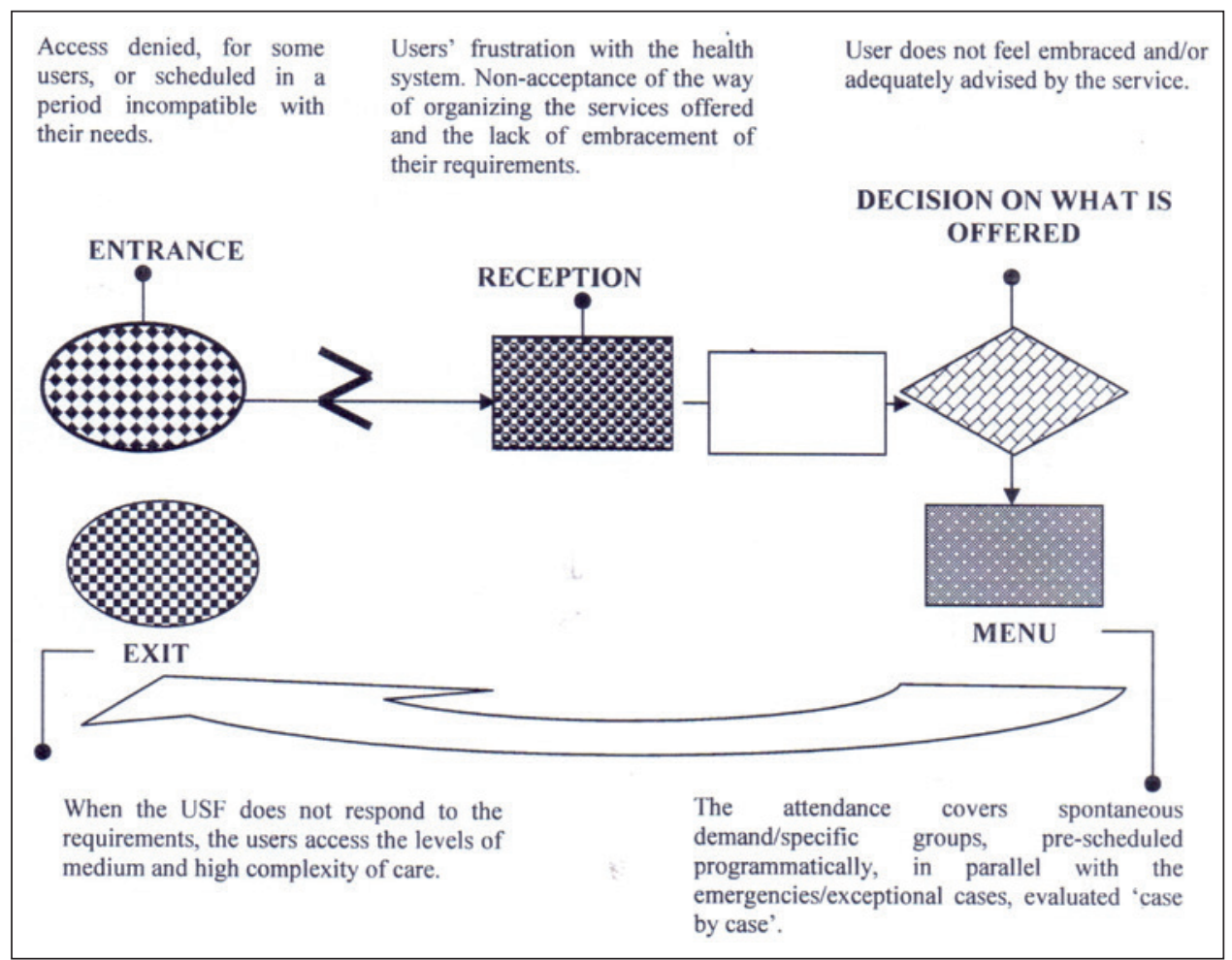

Figure 4 - Analyzing flowchart of the users' access to the practices of the Family Health Team (Situation Three) 
The three scenarios reveal that the workers' autonomy changes the forms of the organization of the access to the services little. The offer is not always compatible with the center's demands, leading a significant part of the users to reveal themselves to be dissatisfied, at certain points, with the production (or lack) of the local health care, which suggests the need for changing the practice and the flow of the attention.

The health workers, in the distinct spaces of the care network, in incorporating the relational dimensions (embracement and link) to the clinic, enable matrix management and viabilize the consolidation of lines of the care for resolution of real and symbolical health problems. ${ }^{26,31-33}$ This necessary re-signification legitimates the professional practice for broadening of the caring acts centered on the users - in their real or imaginary needs, through dialogic processes, which allow changes in the work process, even in locus, traditionally more centered on the procedure. ${ }^{34}$

To this end, one must grasp different perspectives in the act of the care: of the subjectivity of service users and workers; of situations requested by them and of support from managers, among other questions. The other aspects which demonstrated improving the care, such as embracement, establishing links and valuing the mutual respect between worker and service user, are configured in different subjects, as an individual and unique posture which caused (contra) produções in the process of caring as a whole. That is, they are different practices which demonstrate the responsibilization of some members of the team in the act of the health care.

The study revealed contradictions, at specific moments, in which - even in the presence of these aspects which 'qualify the care' - some subjects demarcate their little-welcoming position, valuing bureaucratic and procedure-centered practice. On the other hand, it was possible to perceive actions of continuous education in the services and interface between different practices as relevant contrahegemonic axes to oppose what is instituted. These occasions and practices attest to the subjectivity as an element of the workers which incites, or not, the search for the edification of doing health on the pillars of comprehensive care, allowing one to advance qualitatively in the access through a differentiated practice which is, moreover, under- taken as a team. These data corroborate studies in other realities in the Brazilian context. ${ }^{34-35}$

Specifically, in practice in oral health, the availability of an Oral Health Team (ESB) for two EqSF, in the municipality studied, has caused discontentment among the workers and service users, who criticize the development of the practices which are focused, specific and little resolutive, with difficulty in establishing links with the community. These misunderstandings encourage frequent questioning and complaints from the service users, who feel themselves to be unprotected, and from workers, who even when committed to the service feel themselves to be overloaded and with a limited capacity for producing the care.

These situations can cause demand which is greater than what is offered, not only in the search for oral health services, but in all the actions of the different health workers, which causes appropriate reflections arising from the study: which aspects in the management promote assistential practices which end up maintaining (and generating) demands? Which consequences in the professionals' practices have continuity, as a result of the non-resolution of the users' requirements?

The considerations made so far show, in a certain way, practices geared towards the attendance of health problems through organized or spontaneous demand, centered in the 'logic' of the complaint-diagnosis ${ }^{* *}$. However, regardless of the USF researched, some situations are observed: the lack of material delays the attendances in all the contexts; increase of the demand on the first working day is reinforced by the non-functioning of the center at weekends; and the user ceasing to believe in relation to the resolubility of his problem in primary care, among others. These situations make it more difficult to conceive of ESF as the "gateway" of preference in the healthcare network, which leads the user to seek the satisfaction of her needs at other levels of care (Figure 4).

Access to the primary level of healthcare has improved with the implementation of the ESF. However, the fragmented and un-articulated character in the internal ambit of the public system still persists. ${ }^{10,18,25}$ This assertion does not depend on the geographical localization of the center; on the procedure for attendance intended by the user; on whether the character of the attendance

\footnotetext{
** In colloquial English in North American hospitals, this is known as 'treat'em and street 'em'. Translator's note.
} 
is emergency or not; and also when related to insufficient spaces for specialized medical or dental consultations or complementary tests, referred using referral documents which frequently are not returned counter-referenced (interruption of information flow), although workers and managers assure that they debate the importance of the patient's clinical return to centers at the primary level of care. ${ }^{22,36}$

Emphasis is placed on the need to focus on the struggle for health as a public good which, therefore, requires changes in the practices used, with effective discussion and social participation for probable changes in the management of the SUS. ${ }^{3,37-38}$ This challenge must involve approaches which are not only curative and rehabilitative for the workers, but, above all, cover health promotion activities, based on the undertaking of articulated works between the team members, so as to allow the production of the care in its different dimensions. ${ }^{32}$

In this regard, in one of the USF, new possibilities were observed in the work process: greater community participation in the collective construction of the care, undertaking of significant extramural actions, and horizontalization of powers and knowledges in the center, among others. In this way, the actions focused and restricted on specific groups would have - even if partially - the potential to advance through actions which are compatible with those undertaken by an "integration team". ${ }^{5}$ In this context, with the exception of the physician, frequently substituted due to high turnover, the practice of this worker can occur based on actions which are superficialized and little resolutive. By contrast, the other professionals, of university level, the majority of whom have been inserted for more than five years in the USF studied, raise the qualification of the care in the therapeutic acts, possibly as a result of the establishment of the link-responsibilization and ownership regarding the collective needs of the community.

From this perspective, multiple questions relativize the views regarding the care in the context investigated: the number of health workers and populational demand; the acceptance (or not) of the care model adopted by the municipality; the workers' position in relation to the adoption or not of attitudes which welcome the users' requirements; aspects which cause the service user to need to arrive very early at the USF and face queues in search of attendance, with no effective and secure guarantee of her universal right to health. These implications require, as a consequence, the use of different technologies, able to reflect the subjects immersed in the production of the care so that together they may qualify the health care and the defense of life.

\section{FINAL CONSIDERATIONS}

The flowchart was shown to be a potent tool for identifying the limits existing in the health service, based on a perspective regarding the practices of the EqSF. Within these limits, it is evidenced that in the ESF programmatic actions and specific procedures are undertaken through spontaneous and optimized demand, preferentially by users registered by the ACS in the area covered by the center. The team's practice remains procedurecentered and determines the access based on the health problems of the specific populational groups and on programmatic actions, except for emergency situations, in which any citizen is attended, but there are limits on the access due to the high demand and difficulties in the assistential support at other levels of care of the network.

It may be observed that the responsibilization of the care is not shared by the team, but is, rather, centered on some professionals. The actions employed by the team involve the individual clinical activities with restriction of the actions preventing health problems and actions promoting health.

The difficulty confronted by the population in seeking to guarantee access to the health services revealed the predominance of relationships which varied from satisfactory to conflictual, due to the resolubility, which remains insufficient, regarding the needs demanded in the center, which are beyond the technical capacity of the EqSF or are because of the bureaucratic work process.

As a result, the process of care can be revealed as actions seeking to resolve the users' needs, with tools which go beyond the execution of technical knowledge, but which also appropriate the subjective field, marked by the capacity to listen to what the user says, to become close to his world, and to see him in his uniqueness.

The study, furthermore, indicates the need to advance in the use of technological tools, capable of re-signifying - in all the scenarios studied - the work process, in order to overcome practices centered on the complaint-diagnosis, with resolutive capability, intensifying conflicts and dissatisfactions among subjects-carers (health workers) and 
subjects to be cared for (users). For this, the practice of the above-mentioned subjects involved in the healthcare must be based in ongoing meetings, horizontally, which value reflection and practice over the knowing-doing, guiding the acts of the team to comprehensiveness of the care and to change of the model of care.

\section{REFERENCES}

1. Mendes EV. As redes de atenção à saúde. Ciênc Saúde Coletiva. 2010 Ago; 15(5):2297-305.

2. Merhy EE. Saúde e direitos: tensões de um SUS em disputa, molecularidades. Saúde Soc. 2012 Abr-Jun; 21(2):267-79.

3. Assis MMA, Nascimento MAA, Franco TB, Jorge MSB, organizadores. Produção do cuidado no Programa Saúde da Família: olhares analisadores em diferentes cenários. Salvador (BA): Edufba; 2010.

4. Baremblit G. Compêndio de análise institucional e outras correntes. $3^{\text {a }}$ ed. Rio de Janeiro (RJ): ABDR; 1996.

5. Peduzzi M. Equipe multiprofissional de saúde: conceito e tipologia. Rev de Saúde Pública. 2001 Fev; 5(1):103-9.

6. Assis MMA, Abreu-de-Jesus WL. Acesso aos serviços de saúde: abordagens, conceitos, políticas e modelo de análise. Ciênc Saúde Coletiva. 2012 Nov; 17(11):2865-75

7. Abreu-de-Jesus WL, Assis MMA. Revisão sistemática sobre o conceito de acesso nos serviços de saúde: contribuições do planejamento. Ciênc Saúde Coletiva. 2010 Jan; 15(1):161-70.

8. Barata RB. Social inequalities in access to dental care. Rev Saúde Pública. 2012 Abr; 46(2):207-8.

9. Oliveira LS, Almeida LGN, Oliveira MAS, Gil GB Cunha ABO, Medina MG et al. Acessibilidade a atenção básica em um distrito sanitário de Salvador. Ciênc Saúde Coletiva. 2012 Nov; 17(11):3047-56.

10. Santos AM, Giovanella L, Mendonça MHM, Andrade CLT, Martins MIC, Cunha MS. Práticas assistenciais das Equipes de Saúde da Família em quatro grandes centros urbanos. Ciênc Saúde Coletiva. 2012 Out; 17(10):2687-702.

11. Santos AM, Assis MMA. Saúde bucal: da fragmentação à integralidade. Feira de Santana (BA): UEFS; 2010.

12. Santos IMV, Santos AM. Acolhimento no Programa Saúde da Família: revisão das abordagens em periódicos brasileiros. Rev Salud Pública. 2011 Ago; 13(4):703-16

13. Conill EM, Giovanella L, Almeida PF. Listas de espera em sistemas públicos: da expansão da oferta para um acesso oportuno? Considerações a partir do Sistema Nacional espanhol. Ciênc Saúde Coletiva. 2011 Jun; 16(6):2783-94.
14. Franco TB. Transição tecnológica e inclusão social na saúde. In: Franco TB, Andrade CS, Ferreira VSC, organizadores. A produção subjetiva do cuidado: cartografias da Estratégia Saúde da Família. São Paulo (SP): Hucitec; 2009. p.147-62.

15. Feira de Santana (BA). www.feiradesantana.ba.gov. br. Feira de Santana; 2010. [acesso 2010 Abr 18]: Disponível em: http:/ / www.feiradesantana.ba.gov.br.

16. Bahia. Plano Estadual de Saúde 2008-2011. Rev Baiana Saúde Pública. 2009 Nov; 33(Supl.1):13-87.

17. Merhy EE, Chakkour M, Stéfano E, Stéfano ME, Santos CM, Rodrigues RA et al. Em busca de ferramentas analisadoras das tecnologias em saúde: a informação e o dia a dia de um serviço, interrogando e gerindo trabalho em saúde. In: Merhy EE, Onocko R, organizadores. Agir em saúde: um desafio para o público. 3 ed. São Paulo (SP): Hucitec; 2007. p.113-150.

18. Rodrigues AAAO, Assis MMA. Saúde bucal no Programa de Saúde da Família: sujeitos, saberes e práticas. Vitória da Conquista (BA): UESB; 2009.

19. Lima WCMB, Assis MMA. Acesso restrito e focalizado ao Programa Saúde da Família em Alagoinhas-Bahia, Brasil: demanda organizada para grupos populacionais específicos $\mathrm{x}$ demanda espontânea. Rev Baiana Saúde Pública. 2010 Jul-Set; 34(3):439-49.

20. Castro RCL, Knauth DR, Harzheim E, Hauser L, Duncan BB. Avaliação da qualidade da atenção primária pelos profissionais de saúde: comparação entre diferentes tipos de serviço. Cad Saúde Pública. 2012 Set; 28(9):1772-84.

21. Giovanella L, Mendonça MHM, Almeida PF, Escorel S, Senna MCM, Fausto MCR et al. Saúde da família: limites e possibilidades para uma abordagem integral de atenção primária à saúde no Brasil. Cienc Saúde Coletiva. 2009 Maio-Jun; 14(3):783-94.

22. Santos AM. Gestão do cuidado na microrregião de saúde de Vitória da Conquista (Bahia): desafios para constituição de rede regionalizada com cuidados coordenados pela Atenção Primária à Saúde [tese]. Rio de Janeiro (RJ): Fundação Oswaldo Cruz. Programa de Pós-Graduação em Saúde Pública da Escola Nacional de Saúde Pública; 2013.

23. Mendonça MHM, Martins MIC, Giovanella L, Escorel S. Desafios para gestão do trabalho a partir de experiências exitosas de expansão da Estratégia de Saúde da Família. Ciênc Saúde Coletiva. 2010 Ago; 15(5):2355-65.

24. Assis MMA, Alves JS, Santos AM. Políticas de recursos humanos e a (re)significação das práticas dos trabalhadores no Sistema Único de Saúde (SUS): apontamentos para o debate. Rev. Baiana de Saúde Pública. 2008 Out; 32(1):7-15.

25. Almeida PF, Giovanella L, Mendonça MHM, Escorel S. Desafios à coordenação dos cuidados em saúde: estratégias de integração entre níveis assistenciais 
em grandes centros urbanos. Cad Saúde Pública. 2010 Fev; 26(2):286-98.

26. Ayres JRCM. Cuidado: trabalho e interação nas práticas de saúde. Rio de Janeiro (RJ): Abrasco; 2009.

27. Matumoto M, Fortuna CM, Kawata LS, Mishima SM, Pereira MJB. Cartografia das dores do cuidado no trabalho clínico do enfermeiro na atenção básica. Texto Contexto Enferm. 2013 Abr-Jun [acesso 2013 Ago 10]; 22(2):318-26. Disponível em: http:/ / www. scielo.br/pdf/tce/v22n2/v22n2a07.pdf

28. Gomes R, Moreira MCN, Nascimento EF, Rebello LEFS, Couto MT, Schraiber LB. O homem não vem! Ausência e/ou invisibilidade masculina na atenção primária. Ciênc Saúde Coletiva. 2011 Mar; 16(Supl.1):983-92.

29. Santos AM, Assis MMA; Nascimento MAA, Jorge MSB. Vínculo e autonomia na prática de saúde bucal no Programa de Saúde da Família. Rev Saúde Pública. 2008 Jun; 42(3):464-70.

30. Araujo, IB, Nascimento MAA, Assis MMA. Modelos de atenção à saúde no PSF: práticas e relações. Saúde em Debate. 2010 Jan-Mar; 34(84):119-28.

31. Franco TB, Andrade CS, Ferreira VSC. A produção subjetiva do cuidado: cartografia da Estratégia Saúde da Família. São Paulo (SP): Hucitec; 2009.

32. Cecílio LCO. A morte de Ivan Ilitch, de Leon Tolstói: elementos para se pensar as múltiplas dimensões da gestão do cuidado. Interface: Comunic, Saúde, Educ. 2009; 13(Suppl.1):545-55.

33. Jorge MSB, Sousa FSP, Franco TB. Apoio matricial: dispositivo para resolução de casos clínicos de saúde mental na Atenção Primária à Saúde. Rev Bras Enferm. 2013 Set-Out; 66(5):738-44.

34. Massuda A, Campos GWS. El método de soporte Paideia en el hospital: la experiência del Hospital de Clínicas de la Universidade Estadual de Campinas (HC-Unicamp). Salud Colectiva. 2010 Maio-Ago; 6(2):163-80.

35. Kawata LS, Mishima, SM, Chirelli, MQ, Pereira, MJB. O trabalho cotidiano da Enfermeira na Saúde da Família: utilização de ferramentas da gestão. Texto Contexto Enferm. 2009 Abr-Jun; 18(2):313-20.

36. Gawryszewski ARB, Oliveira DC, Gomes AMT. Acesso ao SUS: representações e práticas de profissionais desenvolvidas nas Centrais de Regulação. Physis: Rev Saúde Coletiva. 2012; 22(1):119-40.

37. Bispo Jr JP, Martins PC. Envolvimento comunitário na Estratégia de Saúde da Família: dilemas entre institucionalização e efetiva participação. Physis: Rev Saúde Coletiva. 2012; 22(4):1313-32.

38. Campos GWS. Cogestão e neoartesanato: elementos conceituais para repensar o trabalho em saúde combinando responsabilidade e autonomia. Ciênc Saúde Coletiva. 2010 Ago; 15(5):2337-44. 